\title{
Species richness of continental gastropod mollusks from a coffee plantation in Jinotega, northern Nicaragua: a first approach
}

\author{
Antonio Mijail Pérez and Marlon Sotelo \\ Asociación Gaia, Colonia 10 de Junio, B-501, Managua, Nicaragua, Tel. 505-22493127; mijail64@gmail.com
}

Received 11-VI-2012 Corrected 20-XII-2012 Accepted 28-I-2012

\begin{abstract}
Continental mollusks of some parts of Nicaragua, such as the Pacific region and the central-north of the country have been relatively well studied, including recently contributions on community ecology for these areas. This paper presents the results of a study on the structure of communities in a coffee farm in the northern zone of the country and at a protected area adjacent to it. The results show a total inventory of 21 species, more or less common values in communities of this group. Species richness at the coffee farm considering all stations (18 species) is higher than species richness at the protected area of Cerro DatanlíEl Diablo (11 species) probably because our sampling effort was larger at the former. It is also worth mentioning that at the latter we found Streptostyla turgidula, an endangered species associated to pristine ecosystems. This species is not found at any of the other sampling stations. Shannon-Weaver Diversity ranged between 2.17 and 2.51, which is consistent with the findings of the authors at other agricultural ecosystems. These data add to the increasingly abundant information on the biodiversity of these ecosystems where production processes take place in what appears to be an equilibrium with the conservation of biodiversity.
\end{abstract}

\section{KEY WORDS}

Terrestrial gastropods, coffee plantation, Northern Nicaragua, diversity.

\begin{abstract}
RESUMEN
Los moluscos continentales de algunas zonas de Nicaragua, como la región del Pacífico y la zona centro-norte del país han sido relativamente bien estudiados, y más recientemente se han publicado contribuciones de mucho interés sobre la ecología de las comunidades de las áreas mencionadas. En el presente trabajo se presentan los resultados de un estudio de estructura de las comunidades de este grupo asociadas con un cafetal de la zona norte del país y en un área protegida colindante. Los resultados muestran un inventario total de 21 especies, 18 especies en la finca cafetalera y 11 en el área protegida de Cerro Datanlí-El Diablo, valores más o menos habituales en comunidades de este grupo. La riqueza de especies en la finca de café teniendo en cuenta todas las estaciones (18 especies), es mayor que la riqueza de especies en el área protegida del Cerro Datanlí-El Diablo (11 especies), probablemente debido a que nuestro esfuerzo de muestreo fue mayor en la primera. También vale la pena mencionar que en el área protegida encontramos Streptostyla turgidula Pfeiffer, 1856, una especie en peligro asociada a ecosistemas prístinos. Esta especie no se encuentra en ninguna de las estaciones de muestreo. La diversidad de Shannon-Weaver osciló entre 2.17 y 2.51 , lo cual es consistente con lo encontrado por los autores en otros sistemas productivos. Estos datos vienen a engrosar la información cada vez más abundante sobre la biodiversidad de estos ecosistemas donde los procesos productivos transcurren en lo que parece ser un equilibrio con la conservación de la biodiversidad.
\end{abstract}

PALABRAS CLAVE

Gasterópodos terrestres, cafetal, Norte de Nicaragua, diversidad.
According to Perez, Vilaseca \& Zione (1996), community studies at landscape level in mollusks or other terrestrial invertebrates are generally scarce. As pointed out by Austin (1985), these have focused, at the global level, mainly on terrestrial vertebrate communities. However, there are works such as the ones by Cameron (1978, 1982, 1986), Walden (1981) and Cowie, Nishida, Basset and Gon (1995) on terrestrial mollusk communities that are of great methodological value. Also, we should mention the contribution of Getz and Uetz (1994), in the southern Appalachian Mountains.

In the case of Nicaragua, the continental molluscan fauna of the Pacific region has been relatively well studied from a taxonomic point of view (Pérez, 1999; 2002; Pérez \& 
López, 2002a; 2002b, 2003; Pérez, Arana, Sotelo \& Bonilla, 2004; Pérez, Altonaga \& López, 2008a), however, there are few quantitative studies of diversity in the level of communities and habitat characterization of species, in this sense we should mention the contributions of Pçerez et al. (2006) and Pérez, Sotelo, Arana and López (2008b) that address the study of diversity and habitat aspects of terrestrial mollusk communities associated with cattle farms in northern Nicaragua, and those of the terrestrial mollusks of the Pacific region, respectively. Both are the first contributions to the study of the ecology of mollusks in Nicaragua.

Despite the scarcity of such studies, they are the basis for assessing the conservation potential of geographic areas of interest and setting priorities for conservation (Dinerstein et al., 1995), because in these assessments should be considered at the same time criteria on diversity of communities and biogeographic value or endemism (Pérez \& López, 1995a).

In this work we present data on structure of the communities of continental gastropod mollusks from Santa Maura coffee Farm, Department of Jinotega in northern Nicaragua and the neighbor protected area of Cerro Datanlí-El Diablo.

\section{METHODOLOGY}

The farm as a whole is a matrix with patches of shadegrown coffee, which are the majority, and patches of coffee without shade. We made a random selection of two spots with shade-grown coffee and one with coffee without shade, from the matrix. We also made a sampling station at the nearby protected area of Cerro Datanlí-El Diablo in order to explore possible differences in species composition and community structure. Temperature varies from $12,5^{\circ} \mathrm{C}$ to $20^{\circ} \mathrm{C}$; with rainfall ranging from 1600 to $2000 \mathrm{~mm}$ per year. The area exhibits a dominance of perennial broad-leaf cloud forest (Fig. 1), with an altitude between 900 and 1650 masl.

The collection was conducted as usual for this group (Altonaga, Gómez, Martín, Prieto \& Rallo, 1994), we had three teams of six people each; each of which sampled a different part of the area. The first group performed two sampling stations in shade-grown coffee, the second made a station in a coffee plantation without shade and the third in a forest of the protected area close to the farm. Sampling was done by free collection of material for two hours by lifting stones, visual inspection of the litter, bark and hollows of trees, logs, etc. In addition, at each station

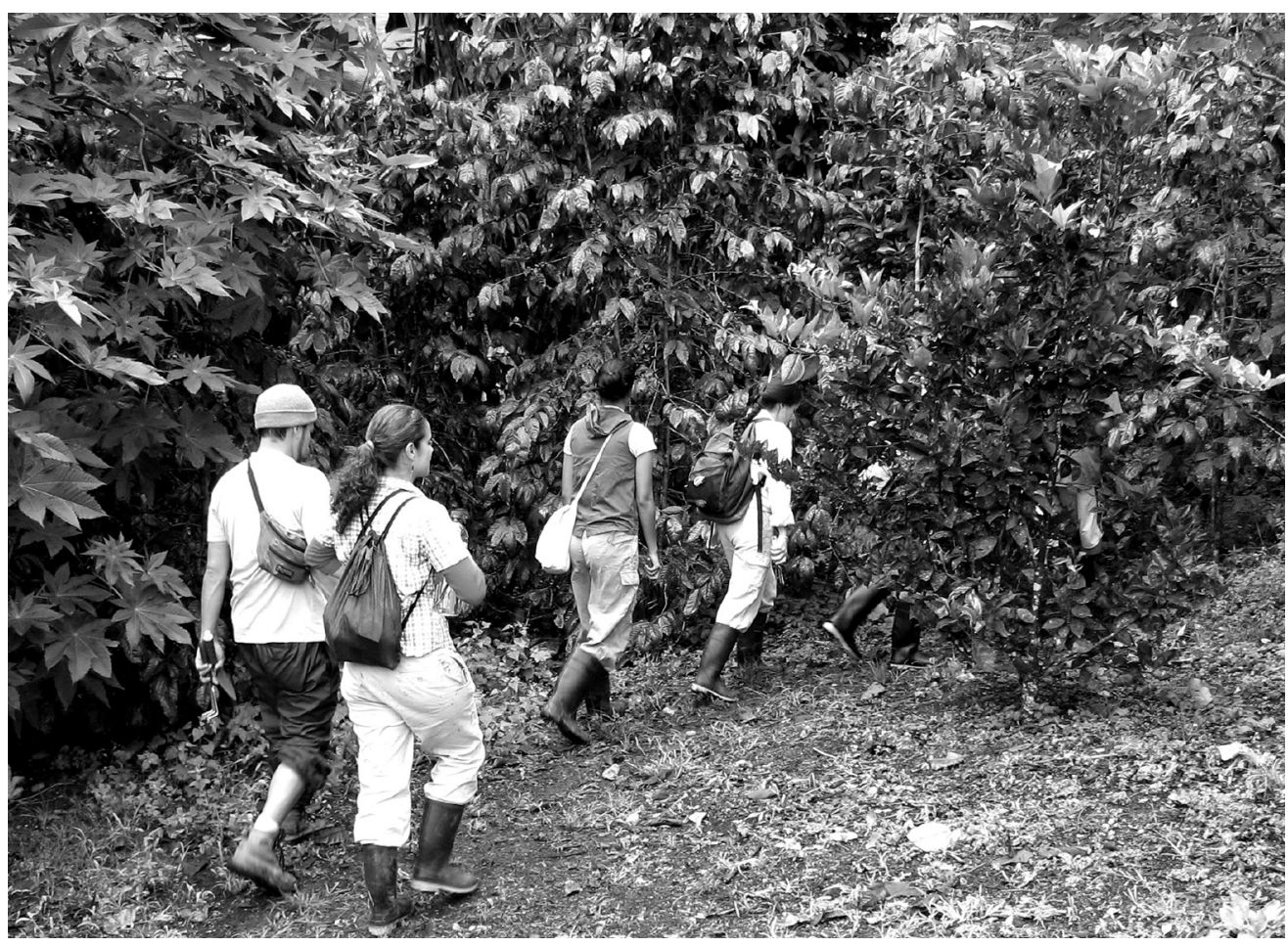

FIG. 1. Patch of shade-grown coffee. 
we collected a sample of litter from an area of approximately $50 \times 50 \mathrm{~cm}$, in order not to overlook the micro-gastropods; samples were placed in labeled plastic bags that were taken to the laboratory, where we separated and identified the material. In this project we collected only living specimens. All separation was performed by hand under a stereo microscope WILD and / or Nikon. For the identification of the material we used the book by Pérez \& López (2002a).

Data were analyzed using PAST (Øyvind, Harper \& Ryan, 2008) to calculate diversity indices of the sites studied. Species richness is the simplest diversity index and consists of the number of species in a given area. The abundance is given by the number of individuals of a species collected per sampling station. Other ecological indices such as $\mathrm{H}^{\prime}$ diversity of Shannon and Weaver, diversity of Simpson 1-D, and J [E1, evenness of Pielou], were calculated. Simpson's index varies from 0 to 1, being 0 the highest diversity. For more details on the indices it is recommended the reading of Magurran (1987). All indices calculated are widely used in Community Ecology and are used in other papers by the authors.

\section{RESULTS}

The results obtained are presented in Table 1, we found a total of 21 species distributed in 19 genera and 12 families, some species restricted to primary ecosystems as $\mathrm{Xe}$ nodiscula taintori Goodrich \& Schalie, 1937 or Radiodiscus sp. (Pérez \& Sotelo, 2011), both having been collected only in the sampling stations made in the shade-grown coffee. Another interesting aspect is that Subulina stolli von Martens, 1898 , which is a new record for the molluscan fauna of the country, was only collected in the protected area Cerro Datanlí-El Diablo.

The species richness values obtained can be considered average for mollusk communities in general [Solem \& Climo, 1985 (5-12 species), Perez et al., 1996 (21 species); 2006 (56 species); 2008 (34 species)], and even communities of mollusks in the country, as those obtained by Pérez et al. (2006) in silvo-pastoral systems from Matiguas and Paiwas, Department of Matagalpa, these authors identified a total of 56 species of mollusks in 41 cattle farms, with species richness values obtained ranging from 13 to 35 species. These values may be considered average even

TABLE 1

Species composition per collecting stations, showing families in taxonomic order.

\begin{tabular}{|c|c|c|c|c|c|}
\hline \multirow[b]{2}{*}{ Species } & \multicolumn{4}{|c|}{ Sampling Stations } & \multirow{2}{*}{$\begin{array}{c}\text { Total } \\
\text { abundance }\end{array}$} \\
\hline & $\begin{array}{l}\text { Shade-Grown } \\
\text { coffee } 1\end{array}$ & $\begin{array}{l}\text { Shade-Grown } \\
\text { coffee } 2\end{array}$ & $\begin{array}{c}\text { Non-Shade } \\
\text { coffee Plantation }\end{array}$ & $\begin{array}{l}\text { Protected } \\
\text { Area }\end{array}$ & \\
\hline \multicolumn{6}{|l|}{$\begin{array}{l}\text { SUBCLASE PROSOBRANCHIA } \\
\text { Milne-Edwards, } 1848\end{array}$} \\
\hline \multicolumn{6}{|l|}{ Familia Poteriidae } \\
\hline Neocylotus dysoni nicaraguense, FC-L & 2 & 1 & 3 & 8 & 14 \\
\hline \multicolumn{6}{|l|}{$\begin{array}{l}\text { SUBCLASE EUTHYNEURA } \\
\text { SUPERORDEN PULMONATA }\end{array}$} \\
\hline \multicolumn{6}{|l|}{ Familia Vertiginidae } \\
\hline Pupisoma dioscoricola, L & 2 & 0 & 0 & 0 & 2 \\
\hline \multicolumn{6}{|l|}{ Familia Subulinidae } \\
\hline Subulina stolli, FC-L & 0 & 0 & 0 & 1 & 1 \\
\hline Lepinaria interstriata, FC-L & 0 & 0 & 4 & 0 & 4 \\
\hline \multicolumn{6}{|l|}{ Familia Spiraxidae } \\
\hline Spiraxis sp., $\mathrm{L}$ & 2 & 1 & 0 & 0 & 3 \\
\hline Salasiella guatemalensis, FC-L & 7 & 0 & 0 & 3 & 10 \\
\hline Streptostyla turgidula, FC-L & 0 & 0 & 0 & 1 & 1 \\
\hline
\end{tabular}

Species collected by free collection are labeled FC and species collected in the litter are labeled L; species collected at both situations are labeled FC-L. 
TABLE 1 (Continued)

Species composition per collecting stations, showing families in taxonomic order.

\begin{tabular}{|c|c|c|c|c|c|}
\hline \multirow[b]{2}{*}{ Species } & \multicolumn{4}{|c|}{ Sampling Stations } & \multirow{2}{*}{$\begin{array}{l}\text { Total } \\
\text { abundance }\end{array}$} \\
\hline & $\begin{array}{l}\text { Shade-Grown } \\
\text { coffee1 }\end{array}$ & $\begin{array}{l}\text { Shade-Grown } \\
\text { coffee2 }\end{array}$ & $\begin{array}{c}\text { Non-Shade } \\
\text { coffee Plantation }\end{array}$ & $\begin{array}{l}\text { Protected } \\
\text { Area }\end{array}$ & \\
\hline \multicolumn{6}{|l|}{ Familia Agriolimacidae } \\
\hline Deroceras reticulatum, FC-L & 3 & 0 & 1 & 0 & 4 \\
\hline \multicolumn{6}{|l|}{ Familia Sagdidae } \\
\hline Xenodiscula taintori, 1937, L & 1 & 0 & 0 & 0 & 1 \\
\hline \multicolumn{6}{|l|}{ Familia Euconulidae } \\
\hline Euconulus pittieri, FC-L & 1 & 1 & 2 & 0 & 4 \\
\hline Guppya gundlachi, FC-L & 6 & 0 & 6 & 3 & 15 \\
\hline Habroconus trochulinus, FC-L & 1 & 5 & 1 & 2 & 9 \\
\hline \multicolumn{6}{|l|}{ Familia Zonitidae } \\
\hline Glyphyalinia indentanta, FC-L & 0 & 0 & 0 & 2 & 2 \\
\hline Hawaia minuscula, $\mathrm{L}$ & 1 & 0 & 0 & 0 & 1 \\
\hline \multicolumn{6}{|l|}{ Familia Thysanophoridae } \\
\hline Thysanophora crinita, FC-L & 0 & 0 & 1 & 0 & 1 \\
\hline Thysanophora hornii, FC-L & 0 & 0 & 8 & 2 & 10 \\
\hline \multicolumn{6}{|l|}{ Familia Bulimulidae } \\
\hline Bulimulus corneus, FC-L & 1 & 0 & 6 & 0 & 7 \\
\hline \multicolumn{6}{|l|}{ Familia Systrophiidae } \\
\hline Drepanostomella pinchoti, FC-L & 0 & 0 & 1 & 1 & 2 \\
\hline Miradiscops opal, FC-L & 4 & 2 & 1 & 2 & 9 \\
\hline Miradiscops panamensis, $\mathrm{L}$ & 1 & 0 & 1 & 2 & 4 \\
\hline \multicolumn{6}{|l|}{ Familia Charopidae } \\
\hline Radiodiscus sp., L & 1 & 1 & 0 & 0 & 2 \\
\hline \multicolumn{6}{|c|}{$\begin{array}{l}\text { Species collected by free collection are labeled FC and species collected in the litter are labeled L; } \\
\text { species collected at both situations are labeled FC-L. }\end{array}$} \\
\hline $\begin{array}{l}\text { when compared to some data fr } \\
\text { and Lopez, 1993a; } 1995 \mathrm{~b} \text {; Pérez } \\
\text { obtained was as usual for this } \\
\text { species, being in the case of th } \\
\text { gundlachi (Pfeiffer, 1839) ( } 15 \\
\text { dysoni nicaraguense Bartsch \& } \\
\text { viduals), Thysanophora hornii (G } \\
\text { guatemalensis Pilsbry, 1919 (10 } \\
\text { trochulinus (Morelet, 1851) (9 inc } \\
\text { resented by a small number of i }\end{array}$ & $\begin{array}{l}\text { cted areas (Perez } \\
\text { 006). Abundance } \\
\text { th few dominant } \\
\text { munities, Guppya } \\
\text { als), Neocyclotus } \\
\text {, } 1942 \text { (14 indi- } \\
\text { 56) and Salasiella } \\
\text { uals), Habroconus } \\
\text { and the rest rep- } \\
\text { ls. }\end{array}$ & \multirow{2}{*}{\multicolumn{4}{|c|}{$\begin{array}{l}\text { richness (S) and diversity H' (Magurran, 1987), are similar at } \\
\text { all collecting stations, except for sampling station } 2 \text { at the } \\
\text { shade-grown coffee; it means that in this case the coffee } \\
\text { without shade has a similar structure to the shade-grown } \\
\text { coffee (sampling station 1), and to the sampling station } \\
\text { at the protected area of Cerro Datanlí- El Diablo, this sug- } \\
\text { gests that either for this group of invertebrates both land } \\
\text { uses are favorable as habitats, or the coffee without shade } \\
\text { is importing faunal elements from the shade-grown cof- } \\
\text { fee. It should be noted that these are the first quantitative } \\
\text { data published on terrestrial gastropod mollusks in the } \\
\text { area farther north of the country. }\end{array}$}} \\
\hline $\begin{array}{l}\text { The results of ecological diver } \\
\text { in Table } 2 \text {, in which one can note }\end{array}$ & $\begin{array}{l}\text { ces are presented } \\
\text { values of species }\end{array}$ & & & & \\
\hline
\end{tabular}


TABLE 2

Ecological indices per collecting stations.

\begin{tabular}{lcccc}
\hline \multirow{2}{*}{ Species } & \multicolumn{4}{c}{ Sampling Stations } \\
\cline { 2 - 5 } & $\begin{array}{c}\text { Shade-Grown } \\
\text { coffee1 }\end{array}$ & $\begin{array}{c}\text { Shade-Grown } \\
\text { coffee2 }\end{array}$ & $\begin{array}{c}\text { Non-Shade coffee } \\
\text { Plantation }\end{array}$ & $\begin{array}{c}\text { Protected } \\
\text { Area }\end{array}$ \\
\hline Taxa S & 14 & 6 & 12 & 11 \\
Individuals (A) & 33 & 11 & 35 & 27 \\
Dominance D & 0,1185 & 0,2727 & 0,1396 & 0,144 \\
Shannon H' & 2,364 & 1,54 & 2,174 & 2,179 \\
Simpson 1-D & 0,8815 & 0,7273 & 0,8604 & 0,856 \\
Equitability J & 0,8958 & 0,8597 & 0,8747 & 0,9087
\end{tabular}

\section{DISCUSSION}

The difference in species richness and abundance, as well as other diversity and evenness indicators between station 1 and station 2 at shade-grown coffee might be due to the gregarious nature of this group instead of differences related to the habitats, since both sites are very similar in terms of soil type, temperature, slope, and canopy shade.

Species richness at the coffee farm considering all stations (18 species), is higher than species richness at the protected area of Cerro Datanlí- El Diablo (11 species) probably because our sampling effort was larger at the former. It is also worth mentioning that at the latter we found Streptostyla turgidula Pfeiffer, 1856, an endangered species associated to pristine ecosystems (Pérez, 1996). This species isn't found at any of the other sampling stations.

Diversity indices, Shannon-Weaver and Simpson, show very similar results among sampling stations except for those related to station 2 at the shade-grown coffee, which showed low values maybe due to the reason explained earlier. The values obtained for Shannon-Weaver index were very similar to the ones obtained at mollusk communities on silvo-pastoral systems of Matiguas and Paiwas, Dpt. of Matagalpa which ranged from 1,45 to 2,93 (Pérez et al., 2006). However the values of the evenness index were much higher than the ones found for the mentioned communities, those ranging from 0,51 to 0,82 and suggesting the existence of communities with an evenness lesser than the ones addressed in this paper, probably due to the fact that human impact is much higher at cattle farms than at coffee plantations, being the latter more conservative of biodiversity (Perfecto, Rice, Greenberg \& van der Voort, 1996; Sepúlveda, Osorio, Zelaya \& Pérez, 2012). At silvopastoral systems of Matiguas and Paiwas Pérez et al. (2006) found 1814 specimens of Bulimulus corneus Sowerby, 1 833, 782 of Beckianum beckianum (Pfeiffer, 1846) and 563 of Cecilioides consobrinus Orbigny, 1855 , followed by other species which not exceeded 350 individuals.

These results provide an important element to take into account regarding the conservation value of this and probably other coffee Farms as well as the protected area of Cerro Datanlí-El Diablo, since we reported a species endemic to Nicaragua, two species new to science, possibly endemics, and various species related to pristine ecosystems. We should mention that the Management Plan of the protected area cites the presence of Quetzal (Pharomachrus mocinno) (MARENA, 2002), an endangered, rare, and very remarkable bird species.

Moguel and Toledo (1999), argue that the relatively high diversity of these systems is probably due to the ecotonal nature of this crop, with a unique mixture of elements from the lowlands and highlands.

In the same area of the current study, at the shadegrown coffee, Andrés and Pérez (2004) published the first list of soil mites in the country listing 19 species, many of them new to science. These results can also contribute to emphasize the conservation values of the area, since mites are among the soil-building organisms.

There are many other publications devoted to the analysis of biodiversity in shade coffee plantations, among which may be mentioned the contributions of Perfecto and Snelling (1995), on diversity of ants, Calvo and Blake (1998), Mogel and Toledo (1999), on diversity of birds, Rojas, Godoy, Hanson, Kleinn and Hilje (2001), on Homoptera, and Pineda, Moreno, Escobar and Halffter (2005), on diversity of frogs, bats, and dung beetles. 


\section{REFERENCES}

Altonaga, K., Gómez, B., Martín, R., Prieto, C., Puente, A.I. \& Rallo, A. (1994). Estudio faunístico y biogeográfico de los moluscos terrestres del norte de la península Ibérica. Vitoria- Gasteiz, España: Eusko Legebiltzarra/ Parlamento Vasco.

Andrés, C. \& Pérez, A.M. (2004). Estudio de los ácaros edáficos de un agroecosistema (cafetal) en la Estación Biológica Don Francisco Chaves en Santa Maura, Jinotega. Gaia, 4,1-11.

Austin, M.P. (1985). Continuum concept, ordination methods, and niche theory. Annual Rev of Ecology and Systematics, $16,39-61$.

Calvo, L. \& Blake, J. (1998). Bird diversity and abundance on two different shade coffee plantations in Guatemala. Bird Conservation International, 8, 297-308.

Cameron, R.A.D. (1978). Life histories, density and biomass in a Woodland Snail community. Journal of Molecular Studies, 48, 159-166.

Cameron, R.A.D. (1982). Terrestrial snail faunas of the Malham area. Field studies, 4, 715-728.

Cameron, R.A.D. (1986). Environment and diversities of forest snail faunas from coastal British Columbia. Malacologia, 27, 341-355.

Cowie, R.H., Nishida, G.M, Basset, Y. \& GON III, S.M. (1995). Patterns of land snail distribution in a montane habitat on the island of Hawaii. Malacologia, 36(1-2),155-169.

Dinerstein, E., Olson, D.M., Graham, D.L., Webster, A.L., Primm, S.A., Bookbinder, M.P. \& Ledec, G. (1995). A Conservation Assessment of the Terrestrial Ecoregions of Latin América and the Caribbean. University of California, USA: The World Bank.

Getz, L.L. \& Uetz, G.W. (1994). Species diversity of terrestrial snails in the southern Appalachian mountains, U.S.A. Malacological Review, 27, 61-74

Magurran, A.E. (1987). Ecological diversity and its measurement. Princeton, USA: Princeton University Press.

MARENA. (2002). Plan de Manejo Reserva Natural Cerro Datanlí-El Diablo. Managua, Nicaragua: MARENA.

Moguel, P. \& Toledo, V. (1999). Biodiversity Conservation in Traditional coffee Systems of Mexico. Conservation Biology, $13(1), 11-21$.

Øyvind, H., Harper, D.A.T. \& Ryan, P.D. (2008). PAST - Paleontological Statistics, ver. 1.79. User's Manual. Recuperado de: http://vanguardia.udea.edu.co/cursos/PAST/past.pdf

Perfecto, I. \& Snelling, R. (1995). Biodiversity and the transformation of a tropical agroecoystems: Ants and coffee plantations. Ecological Applications, 5,1084-1097.

Perfecto, I., Rice, A., Greenberg, R. \& van der Voort, M.E. (1996). Shade coffee: a disappearing refuge for biodiversity. Bioscience, 46,598-608.
Pérez, A.M. (1996). IUCN Red List of Threatened Mollusks from Nicaragua. Recuperado de http://www.iucnredlist.org/.

Pérez, A.M. (1999). Estudio taxonómico y biogeográfico preliminar de la malacofauna continental del Pacífico de Nicaragua. Tesis doctoral. Universidad del País Vasco, España.

Pérez, A.M. (2002). Malacogeographic regionalization, diversity and endemism in the pacific of Nicaragua. Biogeographica, 78(3), 81-94.

Pérez, A.M. \& López, A. (1993). Laguna de Apoyo: Valor paisajístico y diversidad malacológica. Siempreverde, 7,1-2.

Pérez, A.M. \& López, A. (1995ª). La diversidad malacológica en Nicaragua: aproximaciones a un nuevo enfoque. Encuentro, 43, 59-72.

Pérez, A.M. \& López, A. (1995b). Continental snail fauna in La Flor protected area, Rivas Department, Nicaragua. Of Sea and Shore, 18, 64-70.

Pérez, A.M. \& López, A. (2002). Atlas de los moluscos continentales del Pacífico de Nicaragua. Managua, Nicaragua: Editorial UCA.

Pérez, A.M. \& López, A. (2002). Morfología y distribución de Thysanophora crinita (Stylomatophora: Thysanophoridae) en Nicaragua. Revista de Biología Tropical, 50(1),107-116.

Pérez, A.M. \& Sotelo, M. (2011). Moluscos. In Ecoperfiles de la biodiversidad de Nicaragua y su representatividad en el sistema nacional de áreas protegidas. Managua, Nicaagua: MARENA-Embajada de Dinamarca.

Pérez, A.M., Vilaseca, J.C. \& Zione, N. (1996). Sinecología básica de moluscos terrestres en cuatro formaciones vegetales de Cuba. Revista de Biología Tropical, 44(1), 133-146.

Pérez, A.M., Arana, I., Sotelo, M. \& Bonilla, B. (2004). Altitudinal variation of diversity on land snail communities from Maderas Volcano, Ometepe, Nicaragua. Iberus, 22(1)

Pérez, A.M. \& López, A. (2003). Listado de la malacofauna continental del Pacífico de Nicaragua. Malacologia Latinoamerica, 405-461.

Pérez, A.M., Sotelo, M., Ramírez, F., Ramírez, I., López, A. \& Siria, I. (2006). Conservación de la biodiversidad en sistemas silvopastoriles de Matiguás y Rio Blanco, Dpto de Matagalpa, Nicaragua. Ecosistemas, 2006/3.

Pérez, A.M., Altonaga, K. \& López, A. (2008ª). New data on the distribution and morphology of Euglandina obtusa (Pfeiffer, 1844) a Nicaraguan endemism. Iberus, 26(2),127-131.

Pérez, A.M., Sotelo, M., Arana, I. \& López, A. (2008b). Diversidad y aspectos del hábitat en las comunidades de moluscos gasterópodos terrestres en la región del Pacífico de Nicaragua. Revista de Biología Tropical, 56(1), 317-333.

Pineda, E., Moreno, C., Escobar, F. \& Halffter, G. (2005). Frog, bat and dung beetle diversity in cloud forest and coffee agroecosystems of Veracruz, Mexico. Conservation Biology, 19, 400-410. 
Rojas, L., Godoy, C., Hanson, P., Kleinn, C. \& Hilje, L. (2001). Hopper (Homoptera: Auchenorryncha) diversity in shaded coffee systems of Turrialba, Costa Rica. Agroforestry Systems, 53, 171-177.

Sepúlveda, N., Osorio, L., Zelaya, C. \& Pérez, A.M. (2012). Estrategia de adaptación de la caficultura y la ganadería ante el cambio climático. Alianza para la Adaptación, Managua, Nicaragua: CONACAFE, CATIE, CIAT.
Solem, A. \& Climo, F.M. (1985). Structure and habitat correlations of sympatric New Zealand land snail species. Malacologia, 26,1-30

Walden, H. (1981). Communities and diversity of land mollusca in Scandinavian woodland. High diversities communities in taluses and boulder slopes in S.W. Sweden. J. Conchology, 30, 351-377. 
